\title{
Penyuluhan Inovasi Mie Sehat Tanpa Pengawet Bagi Ibu Rumah Tangga di Kelurahan Sidomulyo Kecamatan Medan Tuntungan
}

\author{
Anna Angela Sitinjak ${ }^{1}$, Dimas Frananta Simatupang ${ }^{2 *}$ \\ ${ }^{1}$ Program Studi Teknik Mekanika, Politeknik Teknologi Kimia Industri, Medan, Indonesia \\ ${ }^{2 *}$ Program Studi Teknik Kimia, Politeknik Teknologi Kimia Industri, Medan, Indonesia \\ Email: ${ }^{1}$ annasitinjak@ptki.ac.id, ${ }^{2 *}$ difratas@ptki.ac.id
}

\begin{abstract}
Community service activities (CSA) have been carried out using lecture methods, discussions, and practices regarding innovations in making healthy noodles without preservatives to provide information, knowledge, and skills regarding innovations in making healthy food and encourage and increase entrepreneurship homemakers. The innovation of making healthy noodles with ingredients without preservatives is considered vital because it is beneficial for health and as a step to utilize natural ingredients obtained in the surrounding environment. This activity was attended by 20 housewives in Sidomulyo Village, Medan Tuntungan District, Medan City, North Sumatra Province with different knowledge backgrounds. The CSA training that has been carried out provides understanding and skills to homemakers in processing natural ingredients into healthy food and can increase the economy because it can be commercialized. This CSA training also received a positive response from participants because it could practice directly, and the team provided the freedom to express opinions and develop ideas during the activity. This service activity was considered very useful as much as $65 \%$ and use as much as $35 \%$ of the questionnaire results distributed during the implementation of the activity. Through this CSA activity, it is hoped that the active role of participants in distributing knowledge and skills to the community in the surrounding environment is expected.
\end{abstract}

Keywords: Counseling, Healthy Noodles, CSA

\begin{abstract}
Abstrak
Kegiatan pengabdian kepada masyarakat (PKM) telah dilakukan dengan metode ceramah, diskusi dan praktek mengenai penyuluhan inovasi dalam pembuatan mie sehat tanpa pengawet sebagai upaya memberikan informasi, pengetahuan dan keterampilan mengenai inovasi teknologi pembuatan makanan sehat serta mendorong dan meningkatkan kewirausahaan bagi ibu-ibu rumah tangga. Inovasi pembuatan mie sehat dengan bahan-bahan tanpa pengawet dinilai penting karena bermanfaat untuk kesehatan dan sebagai langkah untuk memanfaatkan bahan-bahan alami yang mudah diperoleh dilingkungan sekitar. Kegiatan ini diikuti sebanyak 20 ibu-ibu rumah tangga di Kelurahan Sidomulyo Kecamatan Medan Tuntungan Kota Medan Provinsi Sumatera Utara dengan latar belakang pengetahuan yang berbeda-beda. Pelatihan PKM yang telah dilakukan memberikan pemahaman dan keterampilan kepada ibu-ibu rumah tangga dalam pengolahan bahan alami menjadi makanan yang sehat dan berpotensi untuk dapat meningkatkan ekonomi karena dapat dikomersialisasikan. Pelatihan PKM ini juga mendapat tanggapan positif dari peserta karena dapat mempraktekkan langsung dan tim memberikan kebebasan untuk peserta menyampaikan pendapat serta mengembangkan ide-ide selama kegiatan berlangsung. Kegiatan pengabdian ini dinilai sangat bermanfaat sebanyak $65 \%$ dan bermanfaat sebanyak $35 \%$ dari hasil kuesioner yang didistribusikan saat pelaksanaan kegiatan. Melalui kegiatan PKM ini diharapkan peran aktif peserta untuk mendistribusikan pengetahuan dan keterampilan kepada masyarakat di lingkungan sekitar.
\end{abstract}

Kata Kunci: Penyuluhan, Mie sehat, PKM

\section{A. PENDAHULUAN}

Kemajuan dunia digital memberikan dampak positif bagi dunia usaha, salah satunya lewat promosi melalui media sosial yang dapat mengurangi biaya promosi suatu usaha. Namun belakangan ini, kesadaran masyarakat akan kesehatan meningkat, sehingga pelaku usaha secara tidak langsung diminta 
untuk menghasilkan produk-produk yang sehat. Inovasi berbagai produk-produk sehat ini dapat dilihat melalui penyuluhan. Inti dari kegiatan penyuluhan merupakan kegiatan untuk memberdayakan masyarakat atau mengembangkan daya kepada masyarakat yang sudah dimiliki menjadi sesuatu yang lebih bermanfaat bagi masyarakat yang bersangkutan (Margono, 2000). Penyuluhan ini dapat dimanfaatkan masyarakat dalam meningkatkan taraf ekonomi keluarganya, dengan bantuan-bantuan dana dari pemerintah. Ketika taraf ekonomi keluarga meningkat maka perekonomian suatu daerah juga meningkat. Perempuan memiliki peranan penting dalam ekonomi keluarga, karena itu program ibu-ibu PKK penting dilakukan (Susila \& Haryanti, 2019). Ibuibu rumah tangga dapat dijangkau oleh para dosen melalui pengabdian masyarakat. Dosen yang merupakan pendidik di suatu pendidikan tinggi memiliki peranan dalam menjangkau kelompokkelompok kecil dalam tatanan masyarakat. Melalui pengetahuan yang dimiliki, dapat mengaplikasikan lewat pengabdian masyarakat sehingga masyarakat dapat menerapkan ilmu tersebut bahkan lebih baik lagi jika dimanfaatkan dan bernilai ekonomis.

Makanan sehat menjadi prioritas utama yang penting untuk menjaga kesehatan tubuh dan menunjang asupan energi untuk melakukan berbagai aktivitas atau kegiatan sehari-hari. Makanan yang sehat juga menjaga metabolisme tubuh yang seimbang dan meningkatkan imunitas tubuh sehingga mengurangi resiko terpapar berbagai macam jenis penyakit. Salah satu olahan makanan sehat sebagai alternatif pengganti nasi adalah mie (Dewi et al., 2021; Muti'ah et al., 2020). Kebutuhan akan konsumsi mie menjadi prioritas kedua setelah nasi sebagai makanan pokok dan cukup digemari oleh masyarakat di Indonesia mulai dari anak-anak, remaja, dewasa hingga lansia. Hal ini dikarenakan mie memiliki karakter makanan yang praktis, mudah diolah dengan berbagai macam resep dan mudah dihidangkan (Alifah et al., 2019; Maryam et al., 2017). Banyaknya manfaat dari mie menjadikan olahan mie memiliki peluang bisnis yang menguntungkan. Namun untuk menjual mie dengan harga yang terjangkau bagi masyarakat di lingkungan sekitar seringkali produsen mie mendapatkan bahan baku yang tidak baik dan menambah beberapa bahan pengawet sehingga mie memiliki masa kadaluarsa yang lama. Mie dengan bahan baku yang tidak baik dimana mengandung beberapa bahan kimia sintesis dan penambahan bahan pengawet menjadikan produk olahan makanan ini menjadi berbahaya jika dikonsumsi secara terus menerus (Sunardi et al., 2017). Badan Pengawas Obat dan Makanan (BPOM) masih menemukan mie-mie di pasaran mengandung formalin dan jika melebihi batas (1,4-14mg) masuk ke dalam tubuh dapat mengakibatkan gangguan pada organ dan sistem tubuh. Formalin yang terakumulasi dalam sel, bereaksi dengan protein seluler (enzim) dan DNA (mitokondria dan nukleus). Formalin yang dikonsumsi juga dapat menyebabkan penyakit kanker (Widyaningsih \& Erni, 2006). Selain itu sampai sekarang ini, mie yang banyak dikonsumsi dengan harga yang relatif murah, terdistribusi di hampir setiap tempat baik perkotaan maupun pedesaan, mudah dimasak dan cepat matang serta dapat disimpan dalam jangka waktu yang lama adalah mie instan (Fu, 2008). Kepopuleran mie instan terjadi karena kepraktisannya ditinjau dari segi manapun namun hal ini juga menjadi masalah bagi kesehatan konsumennya. Hal ini disebabkan sebagian besar mie instan yang beredar dan dijual di pasaran masih belum dianggap menjadi makanan lengkap karena kadar kebutuhan gizi tubuh yang ada pada mie instan tersebut belum cukup dan seimbang. Mie instan yang umumnya terbuat dari bahan tepung terigu yang mengandung karbohidrat dengan jumlah yang cukup besar namun memiliki sedikit protein, mineral dan vitamin. Bukan hanya itu saja, bumbu-bumbu buatan pada mie instan juga dapat berbahaya bagi kesehatan tubuh karena kandungan kimia dan pengawet makanan (Sulistyani, 2014).

Dalam kegiatan PKM ini, produk yang dihasilkan adalah mie basah. Mie basah adalah jenis dari mie yang menjadi produk pangan yang banyak dihasilkan oleh unit kegiatan masyarakat. Mie basah merupakan jenis mie yang telah mengalami proses perebusan dengan air mendidih yang dilakukan setelah melewati tahap pemotongan dan sebelum dipasarkan bebas. Mie basah memiliki kadar air yang mencapai 52\% sehingga untuk daya simpannya maka mie basah ini hanya bisa disimpan dan tahan selama kurang lebih 40 jam pada suhu kamar. Mie basah juga menjadi makanan yang cukup populer dan diminati masyarakat Indonesia serta dijadikan makanan dalam pola diet. Kebanyakan dalam pembuatan mie basah menggunakan bahan-bahan tambahan yang berfungsi untuk meningkatkan sifat fisik dan ketahanan mie basah. Bahan-bahan tambahan yang biasanya digunakan adalah kalium karbonat $\left(\mathrm{K}_{2} \mathrm{CO}_{3}\right)$, natrium karbonat $\left(\mathrm{NaCO}_{3}\right)$ dan polifosfat dengan kadar tertentu yang boleh digunakan (Hasibuan, 2017; Nugrahani, 2005).

Ibu-ibu rumah tangga di Kelurahan Sidomulyo Kecamatan Medan Tuntungan tergabung dalam komunitas ibu-ibu PKK yang mayoritas hanya kaum lelaki yang memiliki pekerjaan untuk mencukupi kebutuhan keluarga. Sebagian kaum perempuan terutama ibu-ibu hanya bertugas di rumah dan sebagian lainnya memiliki pekerjaan sampingan seperti memiliki warung untuk berjualan dan usaha kecil berbasis daring. Berdasarkan observasi dan analisis tim PKM maka kegiatan ini dinilai penting dan bermanfaat bagi ibu-ibu rumah tangga untuk menambah informasi, pengetahuan dan keterampilan untuk berwirausaha dengan membuat 
mie sehat yang mengandung nilai gizi tinggi dan dapat menghasilkan tambahan bagi keluarga mereka.

\section{B. PELAKSANAAN DAN METODE}

Pelayanan kepada masyarakat yang profesional dituntut untuk dapat mengatasi berbagai permasalahan yang sering dihadapi oleh masyarakat di lingkungannya melalui bantuan dari sebuah tim yang ahli di bidangnya. Tim yang dimaksud adalah civitas akademika PTKI Medan yang merupakan pegawai dan para dosen yang bekerja di lingkungan PTKI Medan. Kegiatan pengabdian masyarakat ini dilaksanakan pada bulan September 2019 di salah satu rumah warga (kepala lingkungan) yang berada Kelurahan Sidomulyo Kecamatan Medan Tuntungan yang berjarak $25 \mathrm{~km}$ dari lokasi kampus PTKI Medan.

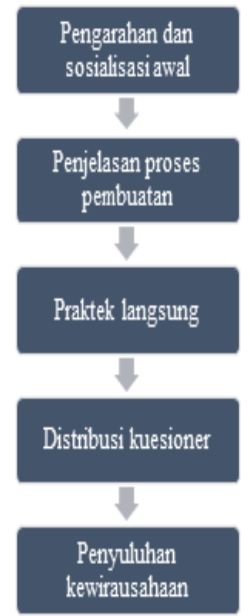

Gambar 1. Diagram alir kegiatan PKM

Kegiatan PKM dilakukan dalam bentuk ceramah, diskusi dan praktek langsung oleh tim dengan melibatkan langsung peserta kegiatan (Nasution et al., 2017; Wipradnyadewi et al., 2017). Ceramah dilakukan dalam pemberian informasi dan pengetahuan mengenai olahan makanan sehat dengan fokus pada mie sehat, kandungan gizi pada mie, pemanfaatan pewarna makanan dari sari buah dan substitusi alternatif tepung terigu dengan tepung mocaf (Philia et al., 2020) hasil produksi laboratorium oleokimia PTKI Medan.

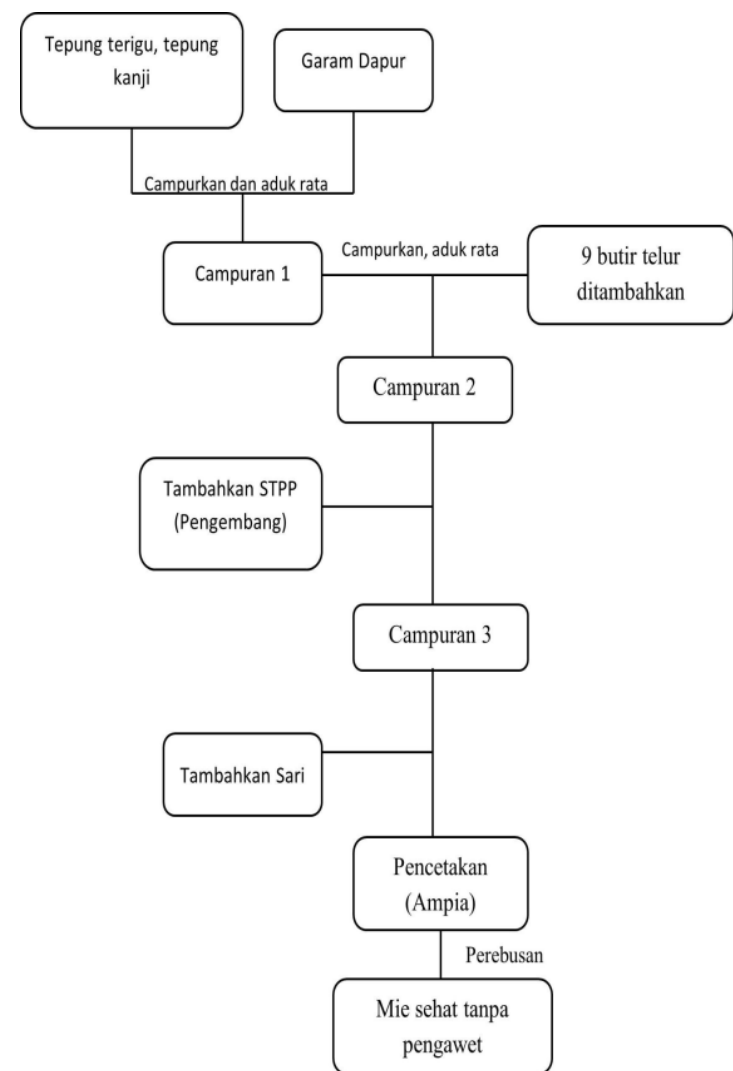

Gambar 2. Prosedur pembuatan mie sehat tanpa pengawet

Kegiatan PKM yang dilakukan diilustrasikan pada Gambar 1 dan diuraikan secara rinci adalah sebagai berikut:

1. Mendistribusikan bukti kehadiran peserta kemudian dilanjutkan dengan memberikan informasi dan pengetahuan dasar mengenai manfaat mie sehat tanpa pengawet menggunakan bahan baku tepung terigu dan tepung mocaf sebagai substitusi tepung terigu dan pewarna makanan dari sari buah dengan metode ceramah dan diskusi tanya jawab. Metode ini dinilai baik untuk menyampaikan konsep-konsep penting sehingga lebih mudah dimengerti dan dikuasai oleh para peserta kegiatan

2. Menjelaskan dan mendeskripsikan proses pembuatan mie sehat dengan mendistribusikan panduan singkat kepada peserta

3. Praktek langsung pembuatan mie sehat yang dipandu oleh tim dengan melibatkan peserta kegiatan dengan metode demonstrasi. Dengan metode ini dapat menunjukkan proses kerja dan diagram alir yaitu tahapan dalam membuat mie sehat dan aman. Demonstrasi dilakukan oleh tim dan kemudian dibantu oleh peserta kegiatan dengan praktek langsung

4. Mendistribusikan kuesioner mengenai kegiatan dan survei terhadap olahan mie sehat 
5. Penyuluhan kewirausahaan mengenai mie sehat dengan metode ceramah dan tanya jawab.

Tahapan pembuatan mie sehat diilustrasikan pada Gambar 2. Bahan-bahan yang diperlukan dalam pembuatan mie sehat meliputi tepung terigu, tepung kanji, tepung mocaf, telur ayam, garam dapur, air dan buah naga sebagai pewarna mie. Adapun alat yang digunakan diantaranya adalah timbangan, baskom, pengaduk, sendok dan ampia.

\section{HASIL DAN PEMBAHASAN}

Konsumsi mie bukan hanya diminati orang dewasa, namun anak-anak juga. Tidak heran jika di media sosial banyak kaum remaja mempromosikan berbagai kuliner di media social. Salah satunya lewat inovasi mie tersebut dengan menghasilkan mie tanpa pengawet dan tetap menarik dan rasa berkualitas. Kegiatan PKM ini diawali dengan komunikasi dan koordinasi dengan kepala lingkungan di Kelurahan Sidomulyo Kecamatan Medan Tuntungan yang nantinya rumah kepala lingkungan ini menjadi lokasi kegiatan. Informasi dasar mengenai kebutuhan dan permasalahan yang dihadapi bagi ibu-ibu rumah tangga dan mencari alternatif solusi melalui kegiatan PKM. Kemudian hasil koordinasi dilaporkan ke Kepala Lurah atas nama Sekretaris Lurah sebagai bahan pertanggungjawaban. Peserta kegiatan PKM terdiri dari 20 ibu-ibu rumah tangga yang berperan aktif sebagai ibu-ibu PKK setempat. Waktu kegiatan dilaksanakan saat para peserta selagi tidak memiliki kegiatan di rumah masing-masing. Para peserta diminta kesediaannya untuk mengisi daftar kehadiran sebelum memulai kegiatan ceramah. Penyuluhan ini dimulai dengan penyampaian materi berisikan informasi dan pengetahuan yang berkaitan dengan manfaat mie sehat tanpa pengawet menggunakan bahan baku tepung terigu dan tepung mocaf sebagai substitusi tepung terigu dan pewarna makanan dari sari buah. Setelah itu dilanjutkan dengan penjelasan singkat prosedur pembuatan mie sehat dan diteruskan dengan praktek langsung oleh tim dengan melibatkan keaktifan peserta seperti pada Gambar 3.

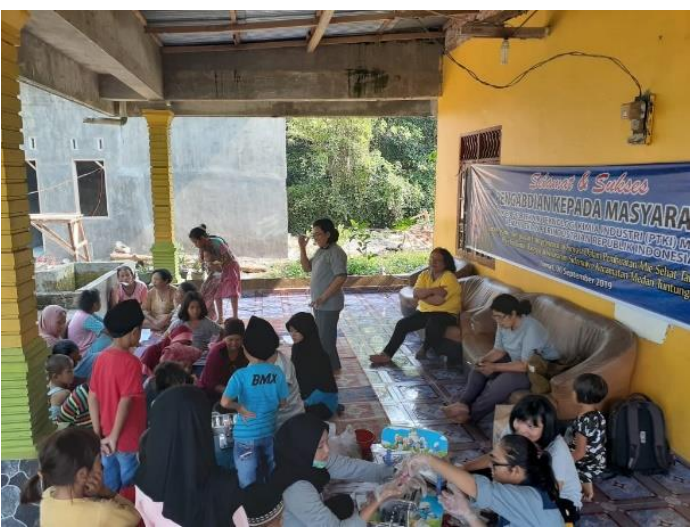

(a)

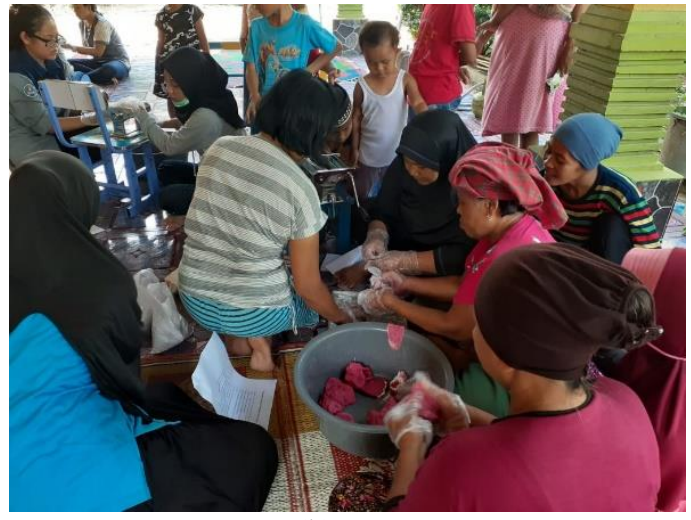

(b)

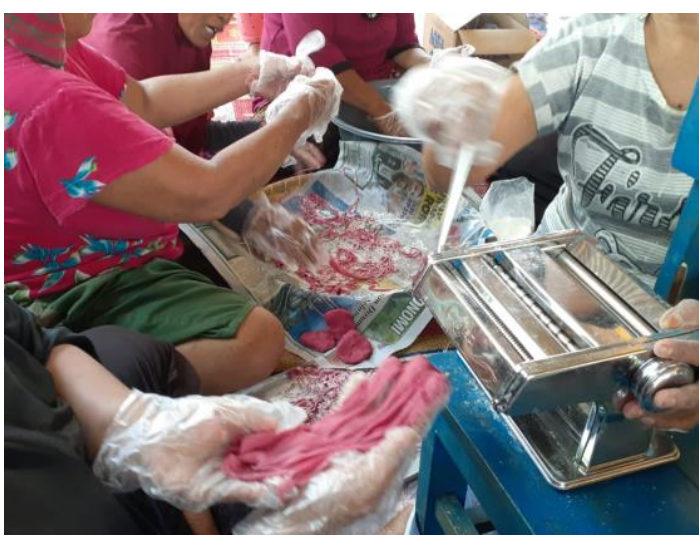

(c)

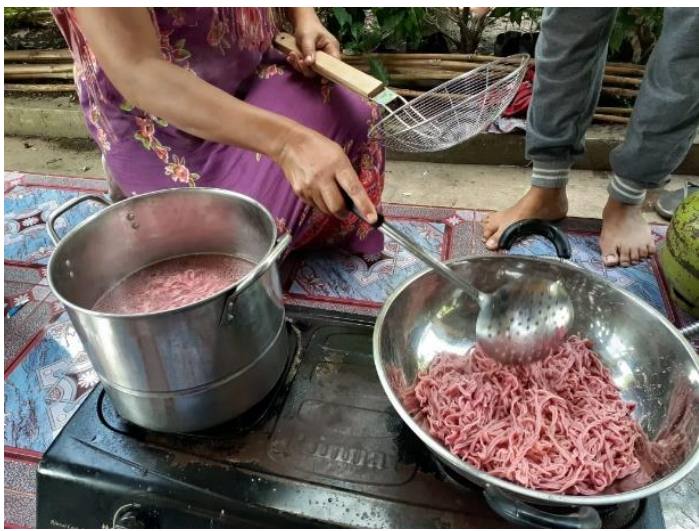

(d)

Gambar 3. Penyuluhan informasi dan praktek langsung pembuatan mie sehat. Instruktur memberikan informasi kepada peserta (a), peserta praktek langsung pembuatan adonan (b), peserta praktek langsung membentuk mie dengan alat (c) dan peserta merebus mie (d)

Pada proses pembuatan mie basah dilakukan pencampuran tepung mocaf substitusi tepung terigu dengan tepung kanji untuk mengurangi pengeluaran dikarenakan harga tepung terigu lebih mahal daripada tepung mocaf. Mie mentah yang dihasilkan dalam kegiatan PKM ini tidak menggunakan bahanbahan kimia yang berbahaya seperti boraks yang umumnya sering ditambahkan untuk meningkatkan kekenyalan dan mie menjadi tahan lama. Telur juga dicampurkan dalam adonan tepung yang memiliki fungsi untuk mengemulsi, melembutkan adonan, 
membangkitkan cita rasa dan menambah nilai gizi dari mie nantinya. Telur memiliki fungsi sebagai pengemulsi karena pada telur mengandung lecithin yang dapat mengemulsikan protein, air dan lemak (Campbell et al., 2005; Souza \& Rojas, 2012). Selanjutnya pada adonan juga ditambahkan STPP (Sodium TriPolyPhosphate) sebagai pengembang adonan dengan jumlah yang tidak melampaui batas. STPP ini digunakan sebagai bahan tambahan dalam produk makanan olahan yang juga berfungsi sebagai pembentuk tekstur dan pengawet makanan. Penggunaan STPP dalam makanan hanya diperbolehkan digunakan dengan kadar 2-9 g/kg bahan makanan (Maharani et al., 2017; Widhaswari et al., 2014). Kemudian ditambahkan sari buah yaitu ekstrak buah naga sebagai pewarna alami untuk meningkatkan daya tarik terhadap mie. Ekstrak buah naga memiliki banyak khasiat diantaranya adalah memiliki antioksidan (fenol, flavonoid, betasianin, dan vitamin C), serat dan asam lemak tak jenuh yang panjang (Prakoso et al., 2017). Selain bahan-bahan yang disebutkan, dalam proses pengolahan menjadi mie basah, ditambahkan juga garam yang berfungsi untuk memperkuat tekstur mie, memberi rasa dan meningkatkan fleksibilitas serta elastisitas mie. Minyak juga ditambahkan agar menghindari lengketnya lembaran mie sehingga tidak saling menempel antara satu lembaran dengan lembaran yang lain dan diperoleh mie basah yang terlihat mengkilap dan memiliki tekstur yang lembut (Hasibuan, 2017). Setelah adonan selesai maka dilanjutkan dengan mencetak lembaran mie dengan ampia dengan memilih pola pencetakan yang sesuai. Adonan dibentuk dan dimasukkan ke alat sehingga nantinya terbentuk lembaran-lembaran mie. Lembaran ini selanjutnya direbus dengan air mendidih. Mie basah ini kemudian siap untuk diolah menjadi makanan sehat.

Partisipasi para peserta yang mengikuti kegiatan PKM ini sangat baik dikarenakan langsung terlibat dalam proses pembuatan mie sehat. Tanggapan ibuibu rumah tangga juga dinilai baik yang ditunjukkan dari sikap antusias, penasaran, keceriaan dan interaksi dua arah yang aktif (diskusi) dengan berbagai pertanyaan yang disampaikan oleh para peserta dan dijawab oleh tim PKM. Mie sehat hasil olahan dengan bahan baku tepung terigu dan substitusi tepung mocaf selanjutnya dimasak dengan resep ibu-ibu rumah tangga dengan cara digoreng dan diberi bumbu dapur yang umumnya digunakan (Gambar 4). Hasilnya tidak terlalu berbeda signifikan antara mie yang dibuat dengan tepung terigu dan tepung mocaf. Namun salah satu keunggulan tepung mocaf adalah harganya yang lebih murah dari tepung terigu sehingga bisa menekan pengeluaran untuk berwirausaha.

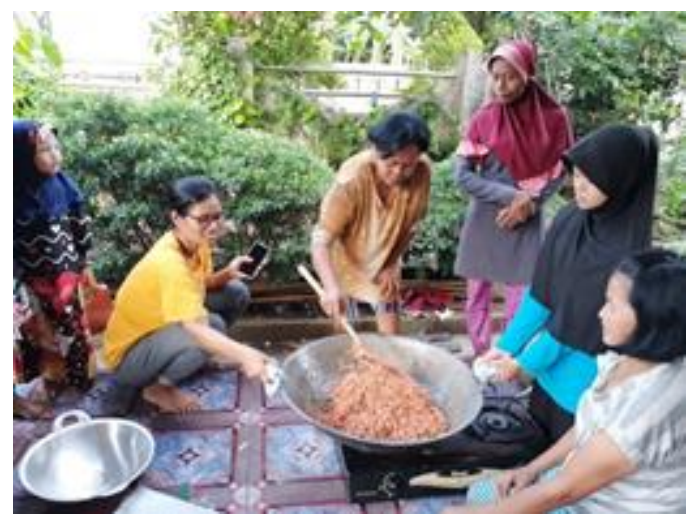

(a)

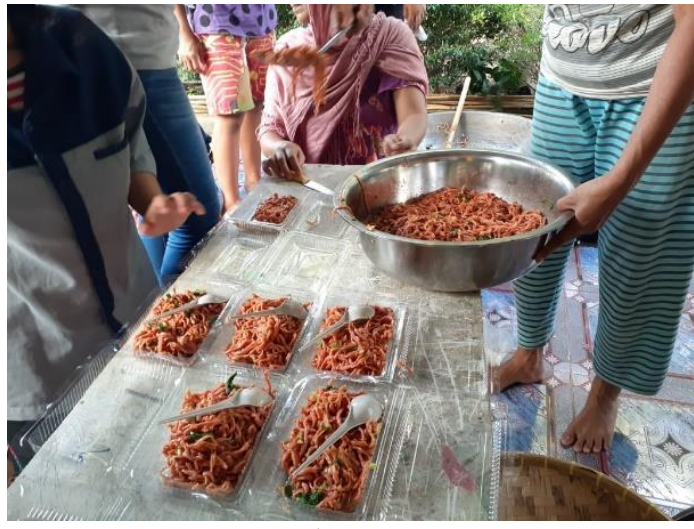

(b)

Gambar 4. Pengolahan mie sehat menjadi mie goreng. Peserta menggoreng mie (a) dan peserta menyajikan mie goreng (b)

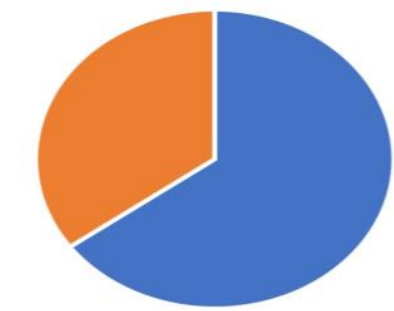

- Sangat bermanfaat - Bermanfaat

Gambar 5. Kuesioner pasca kegiatan PKM

Setelah mie sehat selesai dibuat maka selanjutnya diberikan kuesioner kepada para peserta terhadap kegiatan PKM. Hasil analisa kuesioner menunjukkan bahwa terdapat sebanyak $65 \%$ merasakan kegiatan ini sangat bermanfaat dan 35\% dinilai bermanfaat karena melalui kegiatan PKM ini memberikan informasi dan pengetahuan yang baru (Gambar 5). Melihat antusias para ibu rumah tangga menjadikan kegiatan pelatihan ini juga menjadi tempat diskusi bagi mereka untuk menjadi peluang buka usaha kecil-kecilan. Memberikan pengetahuan dan pelatihan bagi ibu-ibu rumah tangga dapat membantu meningkatkan pengetahuan dalam keluarga tersebut. Berperan sebagai ibu rumah tangga bukanlah keputusan yang mudah karena 
banyak yang mengabaikan mereka, dengan pelatihan ini diharapkan para ibu rumah tangga juga dapat merasakan bahwa mereka juga diperhatikan pemerintah melalui program pengabdian masyarakat oleh dosen.

\section{PENUTUP}

\section{Simpulan}

Bahan pengawet yang sering digunakan pada miemie di pasaran adalah formalin dan boraks sementara untuk pewarna yang digunakan terkadang menggunakan pewarna tekstil dengan alasan agar tahan lama, mie menjadi kenyal dan kelihatan lebih menarik. Namun, seiring pengetahuan yang semakin berkembang, mie-mie yang diolah dengan alami ternyata dapat bertahan lama dan zat warna alami dari buah juga dapat membuat mie lebih menarik dengan memilah buahbuah tertentu seperti buah naga dan mensubstitusi tepung terigu menjadi tepung mocaf menjadi alternatif. Pelatihan mie sehat tanpa pengawet, bukan hanya pelatihan yang biasa saja melainkan juga menjadi sarana untuk berbagi pengetahuan dan ide usaha yang dapat dilakukan oleh ibu rumah tangga. Bahan-bahan dalam pembuatan mie sehat dapat ditemukan dengan mudah dengan harga relatif terjangkau dan proses pembuatannya juga tidak sulit dilakukan. Hasil penyuluhan dan pelatihan ini dinilai $65 \%$ sangat bermanfaat dan $35 \%$ bermanfaat bagi ibu-ibu rumah tangga dan berpeluang bagus untuk melakukan kewirausahaan dalam produk mie sehat tanpa pengawet.

\section{Saran}

Pewarna dalam pembuatan mie sehat tanpa pengawet dapat divariasikan dari bahan-bahan alami selain dari buah naga seperti warna hijau yang dapat diperoleh dari daun bayam, warna orange dari wortel atau warna ungu dari ubi ungu. Olahan mie sehat juga dapat divariasikan penggunaannya selain menjadi mie goreng seperti penggunaan mie dalam makanan mie ayam atau mie bakso.

\section{Ucapan Terima Kasih}

Tim penulis mengucapkan terima kasih kepada peserta yang merupakan ibu-ibu rumah tangga di Kelurahan Sidomulyo Kecamatan Medan Tuntungan telah berpartisipasi aktif dalam kegiatan pengabdian kepada masyarakat. Tim juga mengucapkan terima kasih atas bantuan finansial dari UPPM PTKI Medan demi kelancaran proses kegiatan.

\section{E. DAFTAR PUSTAKA}

Alifah, S., Nurfida, A., \& Hermawan, A. (2019). Pengolahan Sawi Hijau Menjadi Mie Hijau Yang Memiliki Nilai Ekonomis Tinggi Di Desa Sukamanis Kecamatan Kadudampit
Kabupaten Sukabumi. Journal of Empowerment Community, 1(2), 52-58.

Campbell, L., Raikos, V., \& Euston, S. R. (2005). Heat stability and emulsifying ability of whole egg and egg yolk as related to heat treatment. Food Hydrocolloids, 19(3), 533539.

https://doi.org/10.1016/j.foodhyd.2004.10.0 31

Dewi, C. A., Kurniasih, Y., Lukitasari, D., \& Sakban, A. (2021). Pelatihan pembuatan "mikung" (mie kangkung) untuk petani kangkung di kecamatan lingsar lombok barat. Jurnal Lentera Widya, 2(2), 12-18.

Fu, B. X. (2008). Asian Noodles: History, Classification, Raw Materials and Processing. Food Research International, 41, 888-890.

Hasibuan, S. (2017). Pengembangan Kewirausahaan Pangan Mie Sehat di Posdaya Kenanga Kelurahan Meruya Selatan, Jakarta Barat. Seminar Nasional Hasil Penelitian Dan Pengabdian Kepada Masyarakat, November, 46-59.

Maharani, Y., Hamzah, F., \& Rahmayuni. (2017). Pengaruh Perlakuan Sodium Tripolyphosphate (Stpp) Pada Pati Sagu Termodifikasi Terhadap Ketebalan, Transparansi Dan Laju Perpindahan Uap Air Edible Film Effect. JOM FAPERTA, 4(2), 111.

Margono, S. (2000). Kumpulan Bacaan Penyuluhan Pertanian. IPB.

Maryam, S., Damiati, \& Wiratini, I. N. M. (2017). Peningkatan Pengetahuan Dan Keterampilan Ibu Ibu Pkk Kampung Bugis Dalam Pengolahan Mie Sehat. International Journal of Community Service Learning, 1(1), 59-62.

Muti'ah, R., Aisyah, N., Oktaviani, S., Kuspitasari, Kartini, N. A., \& Agustiawan. (2020). Edukasi Pengenalan Mie Sehat Organik Dari Buah Dan Sayuran. COMSEP: Jurnal Pengabdian Kepada Masyarakat, 1(1), 8594.

Nasution, E., Sudaryati, E., \& Asfriyati. (2017). Pemanfaatan beras merah dan jagung dalam pembuatan mie sebagai bahan pangan fungsional. Abdimas Talenta, 2(2), 200-205.

Nugrahani, M. D. (2005). Perubahan karakteristik dan kualitas protein pada mie basah matang yang mengandung formaldehid dan boraks. Institut Pertanian Bogor.

Philia, J., Widayat, Hadiyanto, Suzery, M., \& Budianto, I. A. (2020). Diversifikasi Tepung Mocaf Menjadi Produk Mie Sehat Di PT. Tepung Mocaf Solusindo. Indonesian Journal of Halal, 2(2), 40-45. https://doi.org/10.14710/halal.v2i2.7341

Prakoso, L. O., Yusmaini, H., Thadeus, M. S., \& Wiyono, S. (2017). Perbedaan efek ekstrak buah naga merah (Hylocereus polyrhizus) 
dan ekstrak buah naga putih (Hylocereus undatus) terhadap kadar kolesterol total tikus putih (Rattus norvegicus). Jurnal Gizi Dan Pangan, 12(3), 195-202. https://doi.org/10.25182/jgp.2017.12.3.195$\underline{202}$

Souza, C. J. F., \& Rojas, E. E. G. (2012). Emulsion of systems containing egg yolk, polysaccharides and vegetable oil. Ciencia e Agrotecnologia, 36(5), 543-550. https://doi.org/10.1590/S141370542012000500007

Sulistyani. (2014). Mie Sehat, Nilai Gizi dan Prospek Bisnisnya (Issue September).

Sunardi, Soebiyanto, \& Prasadja, M. E. (2017). IbM Mie Sehat. Jurnal SEMAR, 5(2), 93-103.

Susila, L. N., \& Haryanti, S. S. (2019). Strategi Menciptakan Kemandirian Pangan Melalui Pelatihan Pembuatan Mie Oranik Di Desa
Salam Kecamatan Karangpandan Kabupaten Karanganyar. WASANA NYATA: Jurnal Pengabdian Kepada Masyarakat, 3(1), 4851.

Widhaswari, V. A., Dwi, W., \& Putri, R. (2014). TEPUNG UBI JALAR UNGU The Effect of Chemical Modifications with STTP on Characteristics of Purple Sweet Potato Fluor. 2(3), 121-128.

Widyaningsih, D. T., \& Erni, S. M. (2006). Formalin. Trubus Agrisarana.

Wipradnyadewi, P. A. S., Ina, P. ., Pudja, I. A. R. P., \& Darmayanti, L. P. T. (2017). Pelatihan pembuatan mie dari sayur bayam di desa tihingan kecamatan banjarangkan kabupaten klungkung. Buletin Udayana Mengabdi, 16(3), 90-95. 